\title{
A Review of Ionic Liquids, Their Limits and Applications
}

\author{
Khashayar Ghandi \\ Department of Chemistry, Mount Allison University, Sackville, Canada \\ Email: kghandi@mta.ca
}

Received May 2, 2013; revised September 7, 2013; accepted January 4, 2014

Copyright (C) 2014 Khashayar Ghandi. This is an open access article distributed under the Creative Commons Attribution License, which permits unrestricted use, distribution, and reproduction in any medium, provided the original work is properly cited. In accordance of the Creative Commons Attribution License all Copyrights (C) 2014 are reserved for SCIRP and the owner of the intellectual property Khashayar Ghandi. All Copyright (C) 2014 are guarded by law and by SCIRP as a guardian.

\begin{abstract}
Since environmental pollution caused by chemical and energy industries has increased for several decades, there is a social expectation that scientists and engineers try to design sustainable chemical processes, to generate less hazardous materials and more environmentally friendly sources of energy production. In this review the roles of Ionic Liquids (ILs) and IL based solvent systems as proposed alternative for conventional organic solvents are described. Since there are already many reviews on benefits of ILs, after a very brief review of ILs we focus mostly on aspects that are not covered in other reviews, in particular the known limits of these solvents. In addition, different methods to measure the physicochemical properties relevant to their use in energy storage applications such as fuel cells and batteries are introduced. The physicochemical properties that are reviewed are thermal properties, conductivity and chemical reactivity. The focus of the review is on the literature after 2008 , with the exception of some important historic articles on ILs.
\end{abstract}

\section{KEYWORDS}

Technology; Preference for Quality; Volume of Trade; Vertical Intra-Industry Trade

\section{Introduction}

One of the major sources of waste is solvent losses that end up in the atmosphere or in ground water [1-6]. Solvent use has been reported to account for about $60 \%$ of the overall energy in pharmaceutical production, and it has been responsible for $50 \%$ of post-treatment greenhouse gas emissions [7,8]. Therefore, solvent selection should be considered systematically to improve synthesis conditions within the framework of green chemistry principles.

Various methods and tools have been developed for the identification and selection of appropriate solvents for synthesis. Consequently, there are a number of solvent selection guides available in the literature [1-8]. We have categorized the common solvents in three different classes of preferred, usable, and undesirable (Table 1) [1-8]. The first three items in the preferred column are the most desired solvents and ILs on their own are a large class of solvents. However not all ILs are green solvents.

The focus of this review is on the literature after 2008, with the exception of some important historic articles. We will first have a very brief review of ILs and then we will discuss the limits of these solvents. Most of the limits in the literature are reported for non protic ILs therefore in our review of protic ionic liquids instead of discussion of their limits we focused mostly on their applications in energy industry. Consequently several methods to measure the physicochemical properties relevant to their use in energy industry applications are reviewed.

\section{Ionic Liquids}

Room-temperature ILs, organic salts that are liquid below $100^{\circ} \mathrm{C}$, have received considerable attention as substitutes for volatile organic solvents. Since they are nonflammable, non-volatile and recyclable, they are classified as green solvents. Due to their remarkable properties, such as outstanding solvating potential [9], thermal stability [10] and their tunable propertiesby suitable choices of cations and anions [11], they are consideredfavourable medium candidates for chemical syntheses.

ILsare usually categorized into four types based on their cation segment: 1) alkylammonium-, 2) dialkylimidazolium-, 3) phosphonium- and 4) $\mathrm{N}$-alkylpyridiniumbased ILs (Figure 1). 
Table 1. Guide for solvent selection.

\begin{tabular}{|c|c|c|}
\hline Preferred & Usable & Undesirable \\
\hline $\begin{array}{c}\text { Sc-CO } \\
\text { ILs } \\
\text { Water } \\
\text { Acetone } \\
\text { Ethanol } \\
\text { 2-propanol } \\
\text { 1-propanol } \\
\text { Ethylacetate } \\
\text { Isopropylacetate } \\
\text { Methanol } \\
\text { 1-Butanol } \\
\text { tert-Butyl alcohol }\end{array}$ & $\begin{array}{c}\text { Cyclohexane } \\
\text { Heptane } \\
\text { Toluene } \\
\text { Methyl cyclohexane } \\
\text { Isooctane } \\
\text { Acetonitrile } \\
\text { 2-MeTHF } \\
\text { THF } \\
\text { Xylenes } \\
\text { DMSO } \\
\text { Acetic acid } \\
\text { Ethylene glycol } \\
\text { Methyl Ethyl Ketone }\end{array}$ & $\begin{array}{c}\text { Pentane } \\
\text { Hexane(s) } \\
\text { Di isopropyl ether } \\
\text { Diethyl ether } \\
\text { Dichloromethane } \\
\text { Dichloroethane } \\
\text { Chloroform } \\
\text { Pyridine } \\
\text { Dioxane } \\
\text { Dimethoxyethane } \\
\text { Benzene } \\
\text { Carbon tetrachloride }\end{array}$ \\
\hline
\end{tabular}

Note: $\mathrm{Sc}-\mathrm{CO}_{2}$ is referred to Supercritical- $\mathrm{CO}_{2}$.

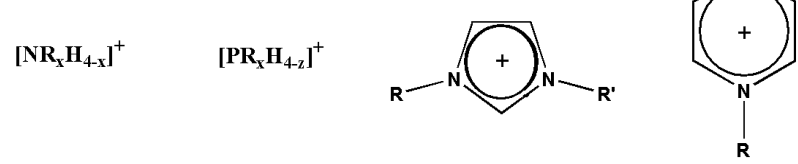

Figure 1. Alkylammonium, phosphonium, dialkylimidazolium and $N$-alkylpyridinium cations.

Although these ILs are used successfully as solvents and catalysts in many reactions, there are some limitations in their use. In the following, we will describe the known advantages and disadvantages of each class of ILs.

The first synthesized IL was an ammonium-based one (ethanolammonium nitrate, EOAN), which was reported by Gabriel in 1888 [12]. Ammonium-based ILs have been used widely as electrolytes in high-energy electrochemical devices owing to their good electrochemical cathodic stabilities, low melting points and low viscosities [13-15].

Popular imidazolium-based ILs are among the most studied ILs. Selection of the imidazolium ring as a cation (Figure 2) is often due to its stability within oxidative and reductive conditions [16], low viscosity of imidazolium ILs and their ease of synthesis [17]. There are also several reports regarding the application of imidazolium-based ILs as catalysts for the improvement of reaction time, yield and chemoselectivity of many organic reactions [18-21].

However, Olofson et al., in 1964 [22], reported on a kinetics studydemonstrating that the proton sandwiched between the two nitrogen atoms (H2)in the imidazolium cation undergoes deuterium exchange in deuterated solvent because of its acidic nature. Two later studiesreported that deprotonation of the imidazolium cation to the highly reactive carbene and hence showedthe noninnocent nature of immidazolium-based ILs under basic conditions $[23,24]$.
In another investigation [25], the low yield of a basecatalyzed Baylis-Hillman reaction in the presence of imidazolium-based ILs was attributed to a side reaction involving the imidazolium-based IL (Scheme 1). This observation also confirmed that using this type of IL under basic conditions needs to be considered with more precaution to avoid unexpected side reactions (Scheme 2).

Pyridinium-based ILs are more novel in comparison with their imidazolium-based counterparts, and research on their stability, reactivity and catalytic role in organic synthesis is still in progress. Although they show poor regioselectivity in palladium-catalyzed telomerization of butadiene with methanol [26], and they have a negative effect on the rate of some Diels-Alder reactions [27], applications of this type of ILs are quite successful in reactions such as Friedel-Crafts [28] and Grignard [29]. The catalytic role of pyridinium-based ILs has been shown to be remarkablein the synthesis of some pharmaceutical agents such as 1,4-dihydropyridine [30], dihydropyrimidinones [31] and 3,5-bis(dodecyloxycarbonyl)1,4-dihydropyridine derivatives [32].

Phosphonium-based ILs aremore novel than the imidazolium- and pyridinium-based ILs. They are more thermally stable (in some cases up to nearly $400^{\circ} \mathrm{C}$ !) [33] in comparison with ammonium and imidazolium salts, and this remarkable property makes them suitable for reactions that are carried out at greater than $100^{\circ} \mathrm{C}$. Phosphonium-based ILs are used as the catalyst and solvent for hydroformylation [34], palladium-catalyzed Heck re-

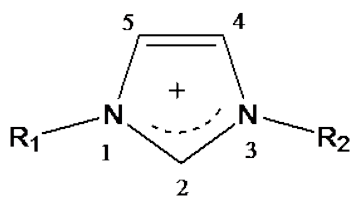

Figure 2. The imidazolium cation.

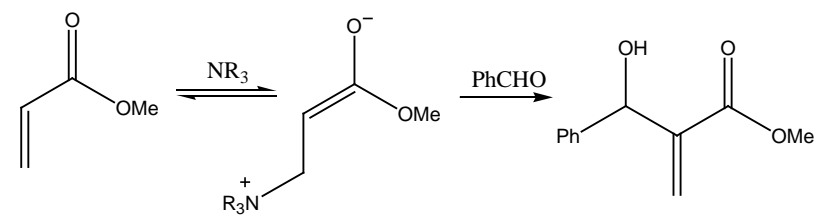

Scheme 1. Base-catalyzed Baylis-Hillman reaction.
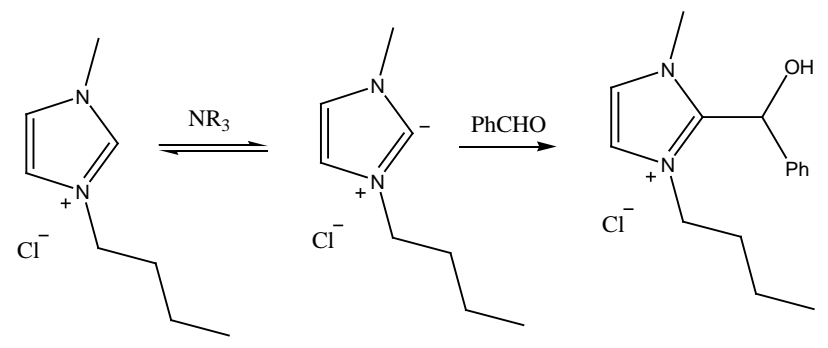

Scheme 2. The side reaction of an imidazolium-based ionic liquid with benzaldehyde in the Baylis-Hillman reaction. 
actions [35] and palladium-mediated Suzuki cross- coupling reactions [35]. In addition, they arealso powerful phase-transfer catalysts for the Halex reaction [36].

Recently, phosphonium-based ILs have been used for $\mathrm{CO}_{2}$ capture [37]. Along with their application in the synthesis of a novel polystyrene-based material [38], the styrenic derivatives of phosphonium-based ILs are used as monomers in the synthesis of phosphonium-containing random copolymers [39]. Thecyclohexadieneylradical in trihexyl (tetradecyl) phosphonium chloride (IL101) [40] has been studied, and the effects of temperature and solvent on the reaction have been investigated using muon techniques at the TRIUMF National Laboratory of Canada [41]. These studies showed [40,41] reactive free radicals do not react with phosphonium ionic liquids.

Although phosphonium-based ILs showed good stability in the presence of bases (even in reactions involving strong bases such as Grignard reagents [42]), they are still susceptible to reaction with small bases [43] (Scheme 3).

Unlike ammonium-based ILs, which undergo Hoffman or -elimination in the presence of a base at high temperature, phosphonium-based ILs tend to decompose to tertiary phosphine oxides and alkanes under alkaline conditions[44] (Equation (1)).

$$
\mathrm{R}_{3} \mathrm{P}-\mathrm{CH}_{2}-\mathrm{R}^{\prime}+\mathrm{OH}^{-} \rightarrow \mathrm{R}_{3} \mathrm{P}=\mathrm{O}+\mathrm{CH}_{3}-\mathrm{R}^{\prime}
$$

\section{Protic ILs}

ILs can be divided into two broad categories: protic ILs (PILs) and aprotic ILs (APILs). PILs are produced through proton transfer from a Brønsted acid to a Brønsted base.

Historically, the first PIL, EOAN was reported in 1888 by Gabriel [12]. There are a large number of reports on the properties of APILs and their applications in different fields [9,45-51]; however, there are few reviews on PILs [52,53].

In comparison with APILs, PILs often have higher conductivity and fluidity as well as lower melting points [54]. They are also cheaper and more convenient to prepare as their synthesis does not involve the formation of byproducts [52]. However, there are several reports of the ability of PILs to form a hydrogen bond network, which can limit the ionicity of PILs in comparison with APILs [55-57]. The hydrogen bonding of PILs has been identified by NMR [55], X-ray diffraction [58] and neutron diffraction [58]. The most studied example of the ability of a PIL to form supramolecular networks through hydrogen bonding is related to ethylammonium nitrate (EAN) [59-61].

Normally, PILs are prepared through the neutralization of a base by an acid [62,63] or the mixture of equimolar amounts of acid and base [54,55]. Ideally, the proton transfer is completed from Brønsted acid to Brønsted base, but, in most cases, a neutral species is formed owing to incomplete proton transfer. Aggregation or the formation of ion complexes also can happen to prevent complete proton transfer, which limits the ionicity of the PILs [51]. Although there is still no standard method to measure the ionicity of PILs, some qualitative techniques such as NMR spectroscopy [56,64], changes in thermal properties as a function of stoichiometry [56,64], IR spectroscopy [64], Raman spectroscopy [64] and ionic conductivity by using Walden plots $[65,66]$ have been used to provide information about the ionicity of PILs. Obviously, proton transfer improves by using stronger acids and bases.

PILs have wide applications in biological systems [52] and chromatography [52,67]. In addition, they have been applied as proton-conducting electrolytes for polymer membrane fuel cells [68-72], because of the advantage of having a defined proton activity as well as high proton conductivity, allowing the fuel cell to operate under nonhumidified and high-temperature conditions. PILs also have been widely used as a Brønsted acid or base [72] in many acid-base-catalyzed organic reactions such as Knoevenagelcondensation [73], the Diels-Alder reaction [74], aldol condensation[75], Fischer esterification [76] and pinacol rearrangement [77] owing to their non-corrosive, non-volatile and recyclable nature in comparison with mineral acids.

Since ILs, including PILs, are great microwave absorbents, they are good candidates for application as a medium or catalyst in many microwave-assisted reactions. Henderson and Byrne [77] used several ammoniumbased PILs as potential mediators for pinacol rearrangements under microwave irradiation; complete conversion was observed in optimized conditions in a pinacol rearrangement of hydrobenzoin (Scheme 4).

Esterification of benzoic acid with a variety of alcohols and a variety of acids with benzoic alcohols are also reported to be efficient when used with some types of imidazolium- or pyridinium-based PILs under microwave irradiation[78] (Scheme 5).

The solvent-free synthesis of coumarins [79], the estrification of salicylic acid [80] and the dehydration of Dfructose and glucose [81] are other examples of using PILs as acidic catalysts under microwave irradiation.

Compared to the disadvantages of ordinary ILs (mostly their reactivity under certain reaction conditions where ILs are used as medium for reaction) there are limited disadvantages of PILs including side reactions during the planned reactions. On the other hand PILs have been considered mostly for their applications in energy industry not as medium for chemistry. For such applications knowledge of their physicochemical properties is important. 


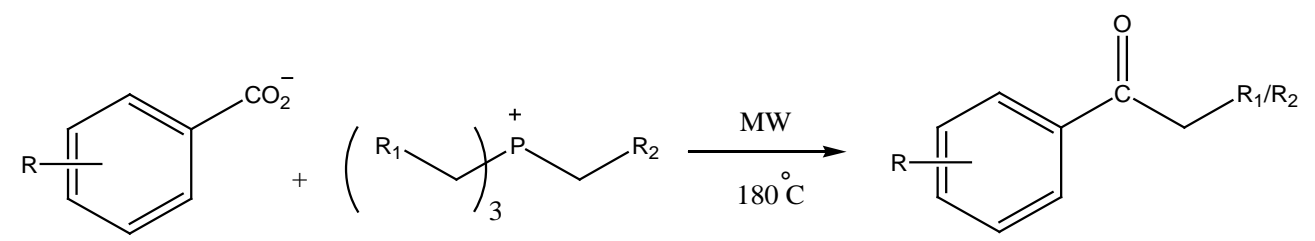

Scheme 3. Reactions of benzoate salts with trihexyl(tetradecyl)phosphonium chloride (IL101) under microwave irradiation.
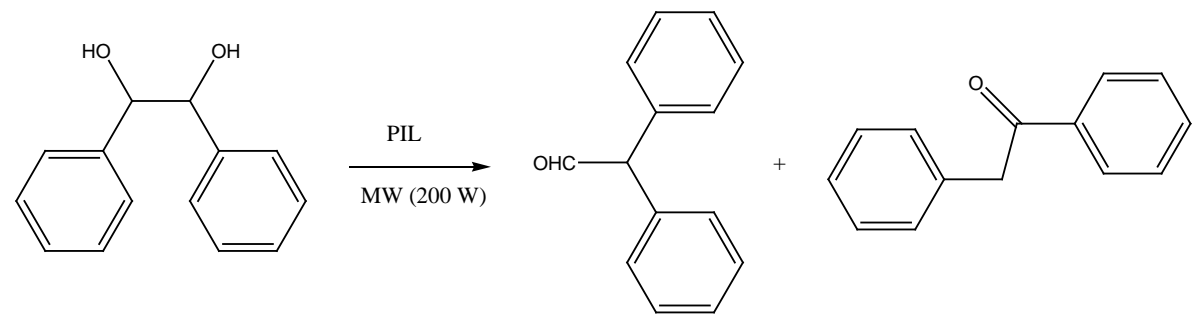

Scheme 4. Microwave-assisted hydrobenzoin pinacol rearrangements mediated by protic ionic liquids (PILs) [78].

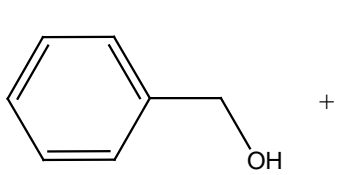<smiles>[R]C(=O)O</smiles>
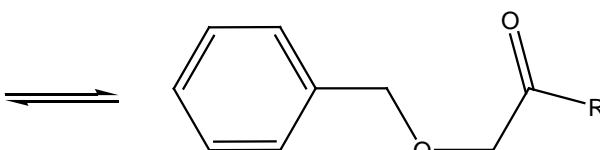

$+\mathrm{H}_{2} \mathrm{O}$

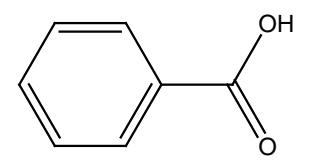

$+\quad \mathrm{R}_{2}-\mathrm{OH}$
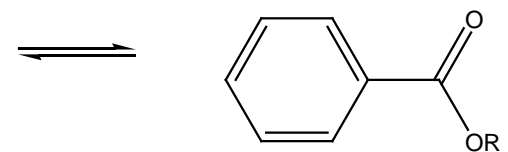

$+\mathrm{H}_{2} \mathrm{O}$

Scheme 5. Fisher esterification reaction in Brønsted acidic ionic liquids under microwave irradiation [79].

\subsection{Physicochemical Properties of PILs}

Different potential applications of PILs rely on their physicochemical properties, which vary based on the structures of the cation and anion used in the system. In the following sections, different methods for the investigation of thermal and ionic properties of PILs are described briefly.

\subsubsection{Thermal-Phase Behaviour}

Differential scanning calorimetry (DSC) is one of the thermoanalytical techniques used to study phase transitionsof materials (Figure 3). In DSC, both the sample and the reference are maintained at the same temperature ( $\left.\Delta T=T_{\mathrm{s}}-T_{\mathrm{r}}=0\right)$ and any heat transfer between the sample and reference materials is recorded against the temperature [82,83]. The reference in the DSC method is a material that does not show phase change over a wide temperature range, Alumina $\left(\mathrm{Al}_{2} \mathrm{O}_{3}\right)$ and silicon carbide (SiC) are mostly used as the reference materials in DSC. The DSC trace usually is plotted as the heat flow versus temperature; deviation from the baseline of the DSC trace is representative of a phase change such as melting of the sample. Steps in the baseline position of the DSC curves usually refer to the glass-transition temperature $\left(T_{\mathrm{g}}\right)$ of the materials, which is a transition that happens for amorphous and semi-crystalline materials including some ILs. For ILs, the $T_{\mathrm{g}}$ indicates the cohesive energy within the salt which is decreased by repulsive Pauli forces and increased through attractive Coulomb and van der Waals interactions [52]. Therefore, it is feasible to reach a lower $T_{\mathrm{g}}$ by decreasing the cohesive energy of the ILs through the modification of the their cations and anions.

Usually the dependence of logarithm of viscosity on inverse temperature, i.e. $\log (\eta)$ vs. $T_{\mathrm{g}} / T$ are used to show the fragility of materials. More deviation from a linear trend indicates more fragility, which means that as the temperature goes up, the viscosities will decrease at a faster rate than the Arrhenius relationship. Almost all the data on room temperature PILs provide evidence that they show fragile behavior [52,84-88].

\subsubsection{Thermal Stability}

Thermogravimetry analysis (TGA) is a type of thermal analysis that examines the mass loss of the sample as a function of temperature in a controlled atmosphere [83] (Figure 4). 


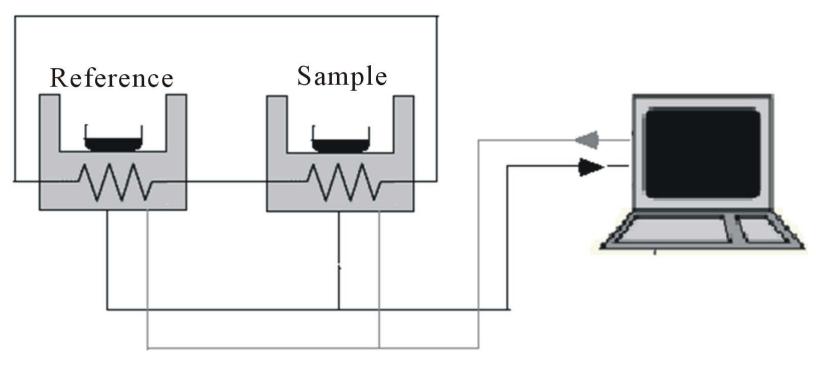

Figure 3. Simple schematic diagram of differential scanning calorimetry (DSC).

It has been established that PILs with large protontransfer energies decompose before reaching their boiling points $[52,84,89]$. The decomposition temperature varies between $100^{\circ} \mathrm{C}$ and $360^{\circ} \mathrm{C}[52,68,85,90]$. PILs with a bis (trifluoromethane) sulfonamide anion (TFSI) with alkylammonium cations, the imidazolium cation, and a variety of heterocyclic cations are known as the most stable PILs with decomposition temperatures of $>200^{\circ} \mathrm{C}$ [52, 90].

\subsubsection{Viscosity}

Viscosity is an important property of ILs for different applications. Normally, materials with greater van der Waals interactions and hydrogen bonding have higher viscosities [52,86,87,90].

Although it has been observed that the size of the PIL components has little effect on viscosity, the structure of the anion has a large effect on the viscosity and usually more than the structure of the cation [88]. This is an interesting observation that needs to be further substantiated by theoretical modeling. Specific structural features can affect viscosity of ILs. E.g. in substituted imidazolium PILs, stacking of the aromatic rings leads to higher viscosity [52,90]. Increasing the cation size by increasing the ring number in lactam-based PILs increases the viscosity by enhancing the cation-anion interactions [68]. Analysis of the temperature dependence of viscosity for PILs with different glass transitions, $T_{\mathrm{g}}$, suggests that PILs in general are among fragile material and the PILs with higher fragility have lower viscosity (Figure 5) [90].

\subsubsection{Conductivity}

The ionic conductivity, which depends on the available charge carriers and their mobility (which depends on viscosity), varies with the molecular weight, and size of the ion. The conductivity of PILs is limited usually by their ion mobility resulting from aggregation $[52,88]$. Therefore, less ionic interaction and more delocalized charge lead to higher conductivity; therefore, high ionic conductivity values will be expected for the stronger Brønsted acids and bases [69,89]. Ion conductivity decreases by increasing the size of the cation (less mobility);

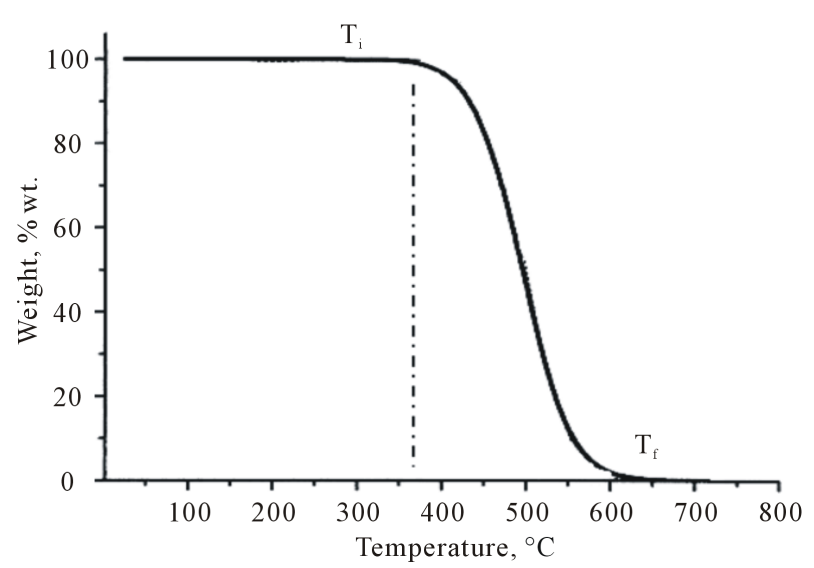

Figure 4. Thermogravimetry analysis (TGA) sample curve for a one-stage process. $T_{\mathrm{i}}$, intial temperature; $T_{\mathrm{f}}$, final temperature.

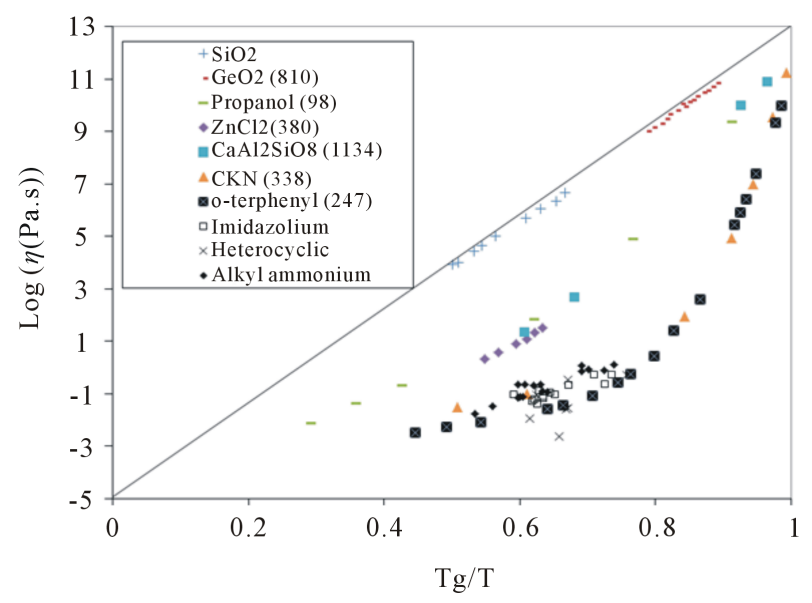

Figure 5. Logarithm of viscosity vs. Tg/T (in Kelvin) for several materials with different glass temperatures (in Kelvin, presented in the legend) as well as for several known PILs [84]. The ellipse shows the range of data for PILs.

consequently, the conductivity of PILs with longer alkyl chains decreases [52]. Therefore, the higher ionic conductivity of the 1-methyl-2-methyl imidazolium-based PILs compared with the 1-benzyl-2 methyl imidazoliumbased PILs [81], and the higher conductivity value for methyl formate over butyl ammonium formate [84], should be due to the increase in the size of the cation. The ionic conductivity of heterocyclic PILs increases with less symmetrical cation structure and smaller molecular weight $[52,68]$. No obvious trend can be found for the anions used in the system: as an example, nitrate has the highest ionic conductivity in ethyl ammonium-based PILs in comparison with formate, acetate, but rate and lactate anions, but in the series of ethanol ammonium-based PILs, nitrate has the lowest ionic conductivity compared with the same anions [84]. There are a few alkylammonium-based PILs, such as methylammoniumformate (MAF), EAN, ethylammonium acetate (EAA), 
and ethylammonium formate (EAF), that have a high ion conductivity over $10 \mathrm{mS} \cdot \mathrm{cm}^{-1}$ at $25^{\circ} \mathrm{C}$ [52].

A Waldon plot, which is of the equivalent conductivity against the log of the fluidity (inverse viscosity), is a good indication of the ionicity of the ILs. The Walden rule is shown in Equation (2), where $\Lambda$ is the molar conductivity and $\eta$ is the viscosity.

$$
\Delta \eta=\text { Constant }
$$

Negative deviation from the straight line can be representative of an incomplete proton transfer or aggregation of PILs [65] (Figure 6). The solid ideal line corresponds to a dilute aqueous $\mathrm{KCl}$ solution in which the system is known to be fully dissociated and to have ions of equal mobility. The presence of parent acid and base molecules in the system can be indicated by vertical deviation from the Walden line as well. The PILs are usually categorized as poor ILs, except for those with a $\mathrm{BF}_{4}$ anion, which have good ionicity [52].

\section{Conclusions}

Over the past five years, ILs have continued to be used significantly as a medium and catalyst for many reactions. Despite the significant potential of ILs in this regard, there are reports that show in some cases ILs react with reactants and therefore they cannot be considered as inert solvents. Therefore synthetic chemists should be cautious when designing reactions in ILs depending on reactions they want to do. Overall PILs are less studied compared to aprotic ILs, however among PILs that have been studied so far there is no report of reactivity of PILs with reagents used for chemical reactions. Moreover PILs have an easily tunable and interesting range of physicochemical properties that make them potential candidates for applications in alkaline and alkaline earth ion batteries and fuel cells.

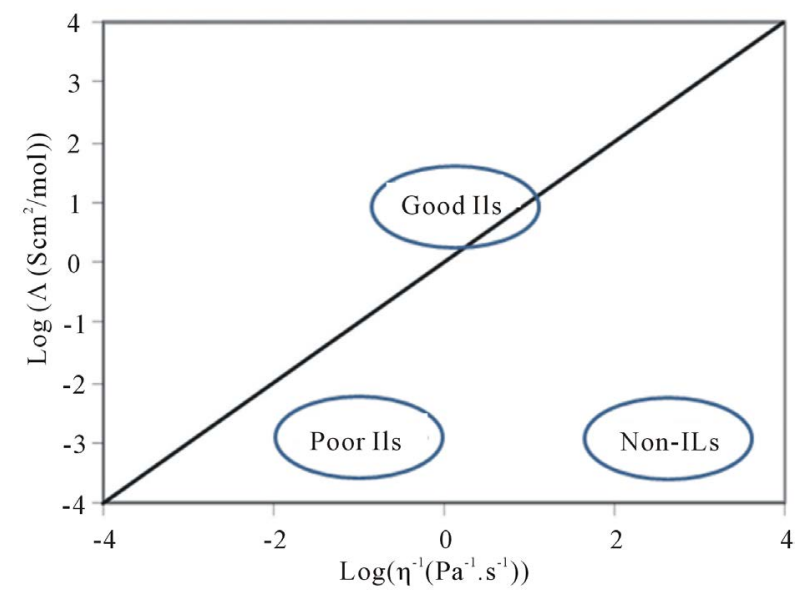

Figure 6. Walden plot of log (equivalent conductivity) against log (fluidity).
There is a significant need for modelling IL and PIL chemical and physicochemical properties to guide the applications of these materials more efficiently. On the experimental side, the least understood reactions in ILs and PILs are the free radical reactions. There is a need for a microscopic understanding of free radical chemistry in ILs and PILs.

\section{REFERENCES}

[1] D. J. C. C. Concepción Jiménez-González, "Green Chemistry and Engineering-A Practical Design Approach," John Wiley \& Sons Inc., Hoboken, 2011, pp. 3-39.

[2] V. K. Ahluwalia, "Green Chemistry, Environmentally Benign Reaction,” CRC Press \& Francis Group, Boca Raton, 2009.

[3] R. A. Sheldon, "Fundamentals of Green Chemistry: Efficiency in Reaction Design," Chemical Society Reviews, Vol. 41, No. 4, 2012, pp. 1437-1451. http://dx.doi.org/10.1039/c1cs15219j

[4] P. J. Dunn, "The Importance of Green Chemistry in Process Research and Development," Chemical Society Reviews, Vol. 41, No. 4, 2012, pp. 1452-1461. http://dx.doi.org/10.1039/c1cs15041c

[5] D. Ghernaout, B. Ghernaout and M. W. Naceur, "Embodying the Chemical Water Treatment in the Green Chemistry-A Review,” Desalination, Vol. 271, No. 1-3, 2011, pp. 1-10.

http://dx.doi.org/10.1016/j.desal.2011.01.032

[6] C. Capello, U. Fischer and K. Hungerbuhler, "What Is a Green Solvent? A Comprehensive Framework for the Environmental Assessment of Solvents," Green Chemistry, Vol. 9, No. 9, 2007, pp. 927-934. http://dx.doi.org/10.1039/b617536h

[7] C. S. Slater and M. Savelski, "A Method to Characterize the Greenness of Solvents Used in Pharmaceutical Manufacture," Journal of Environmental Science and Health, Part A, Vol. 42, No. 11, 2007, pp. 1595-1605.

[8] E. M. Rundquist, C. J. Pink and A. G. Livingston, “Organic Solvent Nanofiltration: A Potential Alternative to Distillation for Solvent Recovery from Crystallisation Mother Liquors," Green Chemistry, Vol. 14, No. 8, 2012, pp. 2197-2205. http://dx.doi.org/10.1039/c2gc35216h

[9] T. Welton, "Room-Temperature Ionic Liquids. Solvents for Synthesis and Catalysis," Chemical Reviews, Vol. 99, No. 8, 1999, pp. 2071-2084. http://dx.doi.org/10.1021/cr980032t

[10] N. Meine, F. Benedito and R. Rinaldi, "Thermal Stability of Ionic Liquids Assessed by Potentiometric Titration,” Green Chemistry, Vol. 12, No. 10, 2010, pp. 1711-1714. http://dx.doi.org/10.1039/c0gc00091d

[11] S. Ahrens, A. Peritz and T. Strassner, "Tunable Aryl Alkyl Ionic Liquids (TAAILs): The Next Generation of Ionic Liquids. Angewandte Chemie International Edition, Vol. 48, No. 42, 2009, pp. 7908-7910. http://dx.doi.org/10.1002/anie.200903399

[12] S. Gabriel and J. Weiner, "Ueber Einige Abkömmlinge 
des Propylamins," Berichte der Deutschen Chemischen Gesellschaft, Vol. 21, No. 2, 1888, pp. 2669-2679. http://dx.doi.org/10.1002/cber.18880210288

[13] M. Armand, F. Endres, D. R. MacFarlane, H. Ohno and B. Scrosati, "Ionic-Liquid Materials for the Electrochemical Challenges of the Future," NatureMaterials, Vol. 8, No. 8, 2009, 8, 621-629. http://dx.doi.org/10.1038/nmat2448

[14] A. Guerfi, M. Dontigny, P. Charest, M. Petitclerc, M. Lagacé, A. Vijh and K. Zaghib, "Improved Electrolytes for Li-Ion Batteries: Mixtures of Ionic Liquid and Organic Electrolyte with Enhanced Safety and Electrochemical Performance,” Journal of Power Sources, Vol. 195, No. 3, 2010, pp. 845-852.

http://dx.doi.org/10.1016/j.jpowsour.2009.08.056

[15] A. Lewandowski and A. Świderska-Mocek, "Ionic Liquids as Electrolytes for Li-Ion Batteries-An Overview of Electrochemical Studies,” Journal of Power Sources, Vol. 194, No. 2, 2009, pp. 601-609. http://dx.doi.org/10.1016/j.jpowsour.2009.06.089

[16] D. Weingarth, I. Czekaj, Z. Fei, A. Foelske-Schmitz, P. J. Dyson, A. Wokaun and R. Kötz, "Electrochemical Stability of Imidazolium Based Ionic Liquids Containing Cyano Groups in the Anion: A Cyclic Voltammetry, XPS and DFT Study,” Journal of The Electrochemical Society, Vol. 159, No. 7, 2012, pp. H611-H615. http://dx.doi.org/10.1149/2.001207jes

[17] C. Wang, H. Luo, X. Luo, H. Li and S. Dai, "Equimolar $\mathrm{CO}_{2}$ Capture by Imidazolium-Based Ionic Liquids and Superbase Systems," Green Chemistry, Vol. 12, No. 11, 2010, pp. 2019-2023. http://dx.doi.org/10.1039/c0gc00070a

[18] J. Safaei-Ghomi, M. Emaeili, et al., "Mild and Efficient Method for Oxidation of Alcohols in Ionic Liquid Media," Digest Journal of Nanomaterials and Biostructures, Vol. 5, No. 4, 2010, pp. 865-871.

[19] J.-I. Yu, H.-Y. Ju, K.-H. Kim and D.-W. Park, "Cycloaddition of Carbon Dioxide to Butyl Glycidyl Ether Using Imidazolium Salt Ionic Liquid as a Catalyst," Korean Journal of Chemical Engineering, Vol. 27, No. 2, 2010, pp. 446-451. http://dx.doi.org/10.1007/s11814-010-0074-1

[20] A. Sarkar, S. R. Roy, N. Parikh and A. K. Chakraborti, "Nonsolvent Application of Ionic Liquids: Organo-Catalysis by 1-Alkyl-3-methylimidazolium Cation Based Room-Temperature Ionic Liquids for Chemoselective $\mathrm{N}$-tert-Butyloxycarbonylation of Amines and the Influence of the C-2 Hydrogen on Catalytic Efficiency,” The Journal of Organic Chemistry, Vol. 76, No. 17, 2011, pp. 7132-7140. http://dx.doi.org/10.1021/jo201102q

[21] D. Sarkar, R. Bhattarai, D. A. Headley and B. Ni, “A Novel Recyclable Organocatalytic System for the Highly Asymmetric Michael Addition of Aldehydes to Nitroolefins in Water," Synthesis, Vol. 2011, 2011, pp. 1993-1997.

[22] S. Sowmiah, V. Srinivasadesikan, M.-C. Tseng and Y.-H. Chu, "On the Chemical Stabilities of Ionic Liquids," Molecules, Vol. 14, No. 9, 2009, pp. 3780-3813. http://dx.doi.org/10.3390/molecules14093780

[23] J. P. Canal, T. Ramnial, D. A. Dickie and J. A. C. Clyburne, "From the Reactivity of N-Heterocyclic Carbenes to New Chemistry in Ionic Liquids," Chemical Communications, Vol. 2006, No. 17, 2006, pp. 1809-1818. http://dx.doi.org/10.1039/b512462j

[24] V. K. Aggarwal, I. Emme and A. Mereu, "Unexpected Side Reactions of Imidazolium-Based Ionic Liquids in the Base-Catalysed Baylis-Hillman Reaction,” Chemical Communications, Vol. 2002, No. 15, 2002, pp. 1612-1613. http://dx.doi.org/10.1039/b203079a

[25] L. Magna, Y. Chauvin, G. P. Niccolai and J.-M. Basset, "The Importance of Imidazolium Substituents in the Use of Imidazolium-Based Room-Temperature Ionic Liquids as Solvents for Palladium-Catalyzed Telomerization of Butadiene with Methanol,” Organometallics, Vol. 22, No. 22, 2003, pp. 4418-4425. http://dx.doi.org/10.1021/om021057s

[26] N. D. Khupse and A. Kumar, "The Cosolvent-Directed Diels-Alder Reaction in Ionic Liquids," The Journal of Physical Chemistry A, Vol. 115, No. 36, 2011, pp. 1021110217. http://dx.doi.org/10.1021/jp205181e

[27] D. J. M. Snelders and P. J. Dyson, "Efficient Synthesis of $\beta$-Chlorovinylketones from Acetylene in Chloroaluminate Ionic Liquids,” Organic Letters, Vol. 13, No. 15, 2011, pp. 4048-4051. http://dx.doi.org/10.1021/ol201182t

[28] L. Ford, F. Atefi, R. D. Singer and P. J. Scammells, "Grignard Reactions in Pyridinium and Phosphonium Ionic Liquids,” European Journal of Organic Chemistry, Vol. 2011, 2011, pp. 942-950.

[29] X. Y. Wu, "Facile and Green Synthesis of 1,4-Dihydropyridine Derivatives in n-Butyl Pyridinium Tetrafluoroborate,” Synthetic Communications, Vol. 42, No. 3, 2011, pp. 454-459.

http://dx.doi.org/10.1080/00397911.2010.525773

[30] A. R. Hajipour and M. Seddighi, "Pyridinium-Based Brønsted Acidic Ionic Liquid as a Highly Efficient Catalyst for One-Pot Synthesis of Dihydropyrimidinones," Synthetic Communications, Vol. 42, No. 2, 2011, pp. 227 235. http://dx.doi.org/10.1080/00397911.2010.523488

[31] K. Pajuste, A. Plotniece, K. Kore, L. Intenberga, B. Cekavicus, D. Kaldre, G. Duburs and A. Sobolev, "Use of Pyridinium Ionic Liquids as Catalysts for the Synthesis of 3,5-Bis(dodecyloxycarbonyl)-1,4-dihydropyridine Derivative," Central European Journal of Chemistry, Vol. 9, No. 1, 2011, pp. 143-148. http://dx.doi.org/10.2478/s11532-010-0132-x

[32] K. Tsunashima, A. Kawabata, M. Matsumiya, S. Kodama, R. Enomoto, M. Sugiya and Y. Kunugi, "Low Viscous and Highly Conductive Phosphonium Ionic Liquids Based on Bis(fluorosulfonyl)amide Anion as Potential Electrolytes,” Electrochemistry Communications, Vol. 13, No. 2, 2011, pp. 178-181. http://dx.doi.org/10.1016/j.elecom.2010.12.007

[33] S. A. Dake, R. S. Kulkarni, V. N. Kadam, S. S. Modani, J. J. Bhale, S. B. Tathe and R. P. Pawar, "Phosphonium Ionic Liquid: A Novel Catalyst for Benzyl Halide Oxidation," Synthetic Communications, Vol. 39, No. 21, 2009, pp. 3898-3904. http://dx.doi.org/10.1080/00397910902840835

[34] H. Cao and H. Alper, "Palladium-Catalyzed Double Carbonylation Reactions of o-Dihaloarenes with Amines in 
Phosphonium Salt Ionic Liquids,” Organic Letters, Vol. 12, No. 18, 2010, pp. 4126-4129.

http://dx.doi.org/10.1021/ol101714p

[35] K. L. Luska, K. Z. Demmans, S. A. Stratton and A. Moores, "Rhodium Complexes Stabilized by PhosphineFunctionalized Phosphonium Ionic Liquids Used as Higher Alkene Hydroformylation Catalysts: Influence of the Phosphonium Headgroup on Catalytic Activity," Dalton Transactions, Vol. 41, No. 43, 2012, pp. 1353313540. http://dx.doi.org/10.1039/c2dt31797d

[36] A. Fan, G.-K. Chuah and S. Jaenicke, "Phosphonium Ionic Liquids as Highly Thermal Stable and Efficient Phase Transfer Catalysts for Solid-Liquid Halex Reactions,” Catalysis Today, Vol. 198, No. 1, 2012, pp. 300-304. http://dx.doi.org/10.1016/j.cattod.2012.02.063

[37] N. D. Harper, N. D. Nizio, A. D. Hendsbee, J. D. Masuda, K. N. Robertson, L. J. Murphy, M. B. Johonson, C. C. Pye and J. A. C. Clyburne, "Survey of Carbon Dioxide Capture in Phosphonium-Based Ionic Liquids and EndCapped Polyethylene Glycol Using DETA (DETA = Diethylenetriamine) as a Model Absorbent," Industrial \& Engineering Chemistry Research, Vol. 50, No. 5, 2011, pp. 2822-2830. http://dx.doi.org/10.1021/ie101734h

[38] K. Ghandi, "Process for the Production of Polystyrene and Novel Polymers in Phosphonium Ionic Liquids," US Patent: 20,120,049,101, 2012.

[39] S. Cheng, M. Zhang, T. Wu, S. T. Hemp, B. D. Mather, R. B. Moore and T. E. Long, "Ionic Aggregation in Random Copolymers Containing Phosphonium Ionic Liquid Monomers," Journal of Polymer Science Part A: Polymer Chemistry, Vol. 50, No. 1, 2012, pp. 166-173. http://dx.doi.org/10.1002/pola.25022

[40] J. M. Lauzon, D. J. Arseneau, J. C. Brodovitch, J. A. C. Clyburne, P. Cormier, B. McCollum and K. Ghandi, "Generation and Detection of the Cyclohexadienyl Radical in Phosphonium Ionic Liquids,” Physical Chemistry Chemical Physics, Vol. 10, No. 39, 2008, pp. 5957-5962. http://dx.doi.org/10.1039/b804800b

[41] B. Taylor, P. J. Cormier, J. M. Lauzon and K. Ghandi, "Investigating the Solvent and Temperature Effects on the Cyclohexadienyl Radical in an Ionic Liquid,” Physica B: Condensed Matter, Vol. 404, No. 5-7, 2009, pp. 936-939. http://dx.doi.org/10.1016/j.physb.2008.11.224

[42] C. J. Bradaric, A. Downard, C. Kennedy, A. J. Robertson and Y. Zhou, "Industrial Preparation of Phosphonium Ionic Liquids,” Green Chemistry, Vol. 5, No. 2, 2003, pp. 143-152. http://dx.doi.org/10.1039/b209734f

[43] M.-C. Tseng, H.-C. Kan and Y.-H. Chu, "Reactivity of Trihexyl(tetradecyl)phosphonium Chloride, a Room-Temperature Phosphonium Ionic Liquid,” Tetrahedron Letters, Vol. 48, No. 52, 2007, pp. 9085-9089. http://dx.doi.org/10.1016/j.tetlet.2007.10.131

[44] K. J. Fraser and D. R. MacFarlane, "Phosphonium-Based Ionic Liquids: An Overview,” Australian Journal of Chemistry, Vol. 62, No. 4, 2009, pp. 309-321. http://dx.doi.org/10.1071/CH08558

[45] N. V. Plechkova, R. D. Rogers and K. R. Seddon, Eds., "Ionic Liquids: From Knowledge to Application," American Chemical Society, Vol. 1030, 2009, p. 472.
[46] J. S. Wilkes, P. Wasserscheid and T. Welton, "Introduction,” In: P. Wasserscheid and T. Welton, Eds., Ionic Liquids in Synthesis, Wiley-VCH Verlag GmbH \& Co. KGaA, Hoboken, 2007, pp. 1-6.

[47] J. D. Holbrey, R. D. Rogers, R. A. Mantz, P. C. Trulove, V. A. Cocalia, A. E. Visser, J. L. Anderson, J. L. Anthony, J. F. Brennecke, E. J. Maginn, T. Welton and R. A. Mantz, "Physicochemical Properties," In: P. Wasserscheid and T. Welton, Eds., Ionic Liquids in Synthesis, Wiley-VCH Verlag GmbH \& Co. KGaA, Hoboken, 2007, pp. 57-174.

[48] S. Sowmiah, C. I. Cheng and Y.-H. Chu, "Ionic Liquids for Green Organic Synthesis,” Current Organic Synthesis, Vol. 9, No. 1, 2012, pp. 74-95. http://dx.doi.org/10.2174/157017912798889116

[49] M. J. A. Shiddiky and A. A. J. Torriero, "Application of Ionic Liquids in Electrochemical Sensing Systems," Biosensors and Bioelectronics, Vol. 26, No. 5, 2011, pp. 1775-1787. http://dx.doi.org/10.1016/j.bios.2010.08.064

[50] C. M. Gordon, "New Developments in Catalysis Using Ionic Liquids,” Applied Catalysis A: General, Vol. 222, No. 1-2, 2001, pp. 101-117. http://dx.doi.org/10.1016/S0926-860X(01)00834-1

[51] F. Karadas, M. Atilhan and S. Aparicio, "Review on the Use of Ionic Liquids (ILs) as Alternative Fluids for $\mathrm{CO}_{2}$ Capture and Natural Gas Sweetening,” Energy \& Fuels, Vol. 24, No. 11, 2010, pp. 5817-5828. http://dx.doi.org/10.1021/ef1011337

[52] T. L. Greaves and C. J. Drummond, "Protic Ionic Liquids: Properties and Applications,” Chemical Reviews, Vol. 108, No. 1, 2007, pp. 206-237. http://dx.doi.org/10.1021/cr068040u

[53] K. E. Johnson, R. M. Pagni and J. Bartmess, “Brønsted Acids in Ionic Liquids: Fundamentals, Organic Reactions, and Comparisons," Monatshefte für Chemie, Vol. 138, No. 11, 2007, pp. 1077-1101. http://dx.doi.org/10.1007/s00706-007-0755-6

[54] H. Markusson, J.-P. Belières, P. Johansson, C. A. Angell and P. Jacobsson, "Prediction of Macroscopic Properties of Protic Ionic Liquids by $a b$ Initio Calculations," The Journal of Physical Chemistry A, Vol. 111, No. 35, 2007, pp. 8717-8723. http://dx.doi.org/10.1021/jp072036k

[55] M. S. Miran, H. Kinoshita, T. Yasuda, M. A. B. H. Susan and M. Watanabe, "Hydrogen Bonds in Protic Ionic Liquids and Their Correlation with Physicochemical Properties," Chemical Communications, Vol. 47, No. 47, 2011, pp. 12676-12678. http://dx.doi.org/10.1039/c1cc14817f

[56] A. Noda, M. A. B. H. Susan, K. Kudo, S. Mitsushima, K. Hayamizu and M. Watanabe, "Brønsted Acid-Base Ionic Liquids as Proton-Conducting Nonaqueous Electrolytes," The Journal of Physical Chemistry B, Vol. 107, No. 17, 2003, pp. 4024-4033. http://dx.doi.org/10.1021/jp022347p

[57] K. Fumino, A. Wulf and R. Ludwig, "Hydrogen Bonding in Protic Ionic Liquids: Reminiscent of Water," Angewandte Chemie International Edition, Vol. 48, No. 17, 2009, pp. 3184-3186. http://dx.doi.org/10.1002/anie.200806224

[58] D. Wakeham, A. Nelson, G. G. Warr and R. Atkin, 
"Probing the Protic Ionic Liquid Surface Using X-Ray Reflectivity,” Physical Chemistry Chemical Physics, Vol. 13, No. 46, 2011, pp. 20828-20835. http://dx.doi.org/10.1039/c1cp22351h

[59] D. F. Evans, S.-H. Chen, G. W. Schriver and E. M. Arnett, "Thermodynamics of Solution of Nonpolar Gases in a Fused Salt. Hydrophobic Bonding Behavior in a Nonaqueous System," Journal of the American Chemical Society, Vol. 103, No. 2, 1981, pp. 481-482. http://dx.doi.org/10.1021/ja00392a049

[60] D. F. Evans, A. Yamauchi, G. J. Wei and V. A. Bloomfield, "Micelle Size in Ethylammonium Nitrate as Determined by Classical and Quasi-Elastic Light Scattering," The Journal of Physical Chemistry, Vol. 87, No. 18, 1983, pp. 3537-3541. http://dx.doi.org/10.1021/j100241a035

[61] A. H. Beesley, D. F. Evans and R. G. Laughlin, "Evidence for the Essential Role of Hydrogen Bonding in Promoting Amphiphilic Self-Assembly: Measurements in 3-Methylsydnone," The Journal of Physical Chemistry, Vol. 92, No. 3, 1988, pp. 791-793. http://dx.doi.org/10.1021/j100314a039

[62] L. Timperman, P. Skowron, A. Boisset, H. Galiano, D. Lemordant, E. Frackowiak, F. Beguin and M. Anouti, "Triethylammonium Bis(tetrafluoromethylsulfonyl)amide protic Ionic Liquid as an Electrolyte for Electrical Double-Layer Capacitors,” Physical Chemistry Chemical Physics, Vol. 14, No. 22, 2012, pp. 8199-8207. http://dx.doi.org/10.1039/c2cp40315c

[63] Z. Du, Z. Li, S. Guo, J. Zhang, L. Zhu and Y. Deng, "Investigation of Physicochemical Properties of LactamBased Brønsted Acidic Ionic Liquids," The Journal of Physical Chemistry B, Vol. 109, No. 41, 2005, pp. 1954219546. http://dx.doi.org/10.1021/jp0529669

[64] B. Schwenzer, N. S. Kerisit and M. Vijayakumar, "Anion Pairs in Room Temperature Ionic Liquids Predicted by Molecular Dynamics Simulation, Verified by Spectroscopic Characterization,” RSC Advances, Vol. 4, No. 11, 2014, pp. 5457-5464.

[65] B. Nuthakki, T. L. Greaves, I. Krodkiewska, A. Weerawardena, M. I. Burgar, R. J. Mulder and C. J. Drummond, "Protic Ionic Liquids and Iconicity," Australian Journal of Chemistry, Vol. 60, No. 1, 2007, pp. 21-28. http://dx.doi.org/10.1071/CH06363

[66] J. Stoimenovski, E. I. Izgorodina and D. R. MacFarlane, "Ionicity and Proton Transfer in Protic Ionic Liquids," Physical Chemistry Chemical Physics, Vol. 12, No. 35, 2010, pp. 10341-10347. http://dx.doi.org/10.1039/c0cp00239a

[67] M. Yoshizawa, W. Xu and C. A. Angell, "Ionic Liquids by Proton Transfer: Vapor Pressure, Conductivity, and the Relevance of $\Delta \mathrm{pKa}$ from Aqueous Solutions," Journal of the American Chemical Society, Vol. 125, No. 50, 2003, pp. 15411-15419. http://dx.doi.org/10.1021/ja035783d

[68] C. F. Poole, "Chromatographic and Spectroscopic Methods for the Determination of Solvent Properties of Room Temperature Ionic Liquids," Journal of Chromatography A, Vol. 1037, No. 1-2, 2004, pp. 49-82. http://dx.doi.org/10.1016/j.chroma.2003.10.127

[69] W. Wang, L. Shao, W. Cheng, J. Yang and M. He, "Brønsted Acidic Ionic Liquids as Novel Catalysts for Prins Reaction,” Catalysis Communications, Vol. 9, No. 3, 2008, pp. 337-341. http://dx.doi.org/10.1016/j.catcom.2007.07.006

[70] S.-Y. Lee, A. Ogawa, M. Kanno, H. Nakamoto, T. Yasuda and M. Watanabe, "Nonhumidified Intermediate Temperature Fuel Cells Using Protic Ionic Liquids,” Journal of the American Chemical Society, Vol. 132, No. 28, 2010, pp. 9764-9773.

http://dx.doi.org/10.1021/ja102367x

[71] A. Fernicola, S. Panero and B. Scrosati, "Proton-Conducting Membranes Based on Protic Ionic Liquids,” Journal of Power Sources, Vol. 178, No. 2, 2008, pp. 591-595. http://dx.doi.org/10.1016/j.jpowsour.2007.08.079

[72] H. Ye, J. Huang, J. J. Xu, N. K. A. C. Kodiweera, J. R. P. Jayakody and S. G. Greenbaum, "New Membranes Based on Ionic Liquids for PEM Fuel Cells at Elevated Temperatures,” Journal of Power Sources, Vol. 178, No. 2, 2008, pp. 651-660. http://dx.doi.org/10.1016/j.jpowsour.2007.07.074

[73] H. Nakamoto and M. Watanabe, "Bronsted Acid-Base Ionic Liquids for Fuel Cell Electrolytes,” Chemical Communications, No. 24, 2007, pp. 2539-2541. http://dx.doi.org/10.1039/b618953a

[74] N. B. Darvatkar, A. R. Deorukhkar, S. V. Bhilare and M. M. Salunkhe, "Ionic Liquid-Mediated Knoevenagel Condensation of Meldrum's Acid and Aldehydes," Synthetic Communications, Vol. 36, No. 20, 2006, pp. 3043-3051. http://dx.doi.org/10.1080/00397910600775218

[75] E. Janus, I. Goc-Maciejewska, M. Łożyński and J. Pernak, "Diels-Alder Reaction in Protic Ionic Liquids," Tetrahedron Letters, Vol. 47, No. 24, 2006, pp. 4079-4083. http://dx.doi.org/10.1016/j.tetlet.2006.03.172

[76] A. Zhu, T. Jiang, D. Wang, B. Han, L. Liu, J. Huang, J. Zhang and D. Sun, "Direct Aldol Reactions Catalyzed by 1,1,3,3-Tetramethylguanidine Lactate without Solvent," Green Chemistry, Vol. 7, No. 7, 2005, pp. 514-517. http://dx.doi.org/10.1039/b501925g

[77] H. Zhou, J. Yang, L. Ye, H. Lin and Y. Yuan, "Effects of Acidity and Immiscibility of Lactam-Based BronstedAcidic Ionic Liquids on Their Catalytic Performance for Esterification," Green Chemistry, Vol. 12, No. 4, 2010, pp. 661-665. http://dx.doi.org/10.1039/b921081d

[78] L. C. Henderson and N. Byrne, "Rapid and Efficient Protic Ionic Liquid-Mediated Pinacol Rearrangements under Microwave Irradiation,” Green Chemistry, Vol. 13, No. 4, 2011, pp. 813-816. http://dx.doi.org/10.1039/c0gc00916d

[79] X. Li, W. Eli and G. Li, "Solvent-Free Synthesis of Benzoic Esters and Benzyl Esters in Novel Brønsted Acidic Ionic Liquids under Microwave Irradiation,” Catalysis Communications, Vol. 9, No. 13, 2008, pp. 2264-2268. http://dx.doi.org/10.1016/j.catcom.2008.05.015

[80] H. Shi, W. Zhu, H. Li, H. Liu, M. Zhang, Y. Yan and Z. Wang, "Microwave-Accelerated Esterification of Salicylic Acid Using Brönsted Acidic Ionic Liquids as Catalysts,” 
Catalysis Communications, Vol. 11, No. 7, 2010, pp. 588591. http://dx.doi.org/10.1016/j.catcom.2009.12.025

[81] X. Tong and Y. Li, "Efficient and Selective Dehydration of Fructose to 5-Hydroxymethylfurfural Catalyzed by Brønsted-Acidic Ionic Liquids,” ChemSusChem, Vol. 3, No. 3, 2010, pp. 350-355.

http://dx.doi.org/10.1002/cssc.200900224

[82] P. Gabbott, "Principles and Applications of Thermal Analysis," Wiley, Hoboken, 2008. http://dx.doi.org/10.1002/9780470697702

[83] M. Sorai and N. N. Gakkai, "Comprehensive Handbook of Calorimetry and Thermal Analysis,” Wiley, Hoboken, 2004.

[84] J.-P. Belieres and C. A. Angell, "Protic Ionic Liquids: Preparation, Characterization, and Proton Free Energy Level Representation,” The Journal of Physical Chemistry B, Vol. 111, No. 18, 2007, pp. 4926-4937. http://dx.doi.org/10.1021/jp067589u

[85] M. A. B. H. Susan, A. Noda, S. Mitsushima and M. Watanabe, "Bronsted Acid-Base Ionic Liquids and Their Use as New Materials for Anhydrous Proton Conductors," Chemical Communications, No. 8, 2003, pp. 938-939. http://dx.doi.org/10.1039/b300959a

[86] S. R. Varma, "Solvent-Free Organic Syntheses Using Supported Reagents and Microwave Irradiation,” Green
Chemistry, Vol. 1, No. 1, 1999, pp. 43-55. http://dx.doi.org/10.1039/a808223e

[87] A. Davoodnia, M. M. Heravi, Z. Safavi-Rad and N. Tavakoli-Hoseini, “Green, One-Pot, Solvent-Free Synthesis of 1,2,4,5-Tetrasubstituted Imidazoles Using a Brønsted Acidic Ionic Liquid as Novel and Reusable Catalyst," Synthetic Communications, Vol. 40, No. 17, 2010, pp. 2588-2597. http://dx.doi.org/10.1080/00397910903289271

[88] T. L. Greaves, A. Weerawardena, C. Fong, I. Krodkiewska and C. J. Drummond, "Protic Ionic Liquids: Solvents with Tunable Phase Behavior and Physicochemical Properties," The Journal of Physical Chemistry B, Vol. 110, No. 45, 2006, pp. 22479-22487. http://dx.doi.org/10.1021/jp0634048

[89] A. Davoodnia, M. Bakavoli, R. Moloudi, N. Tavakoli-Hoseini and M. Khashi, "Highly Efficient, One-Pot, SolventFree Synthesis of 2,4,6-Triarylpyridines Using a Brønsted Acidic Ionic Liquid as Reusable Catalyst,” Monatshefte für Chemie, Vol. 141, No. 8, 2010, pp. 867-870. http://dx.doi.org/10.1007/s00706-010-0329-x

[90] S. Nazari, K. Ghandi, S. B. Cameron and M. B. Johonson, "Physicochemical Properties of Imidazo Pyridine Protic Ionic Liquids,” Journal of Materials Chemistry A, Vol. 1, No. 38, 2013, pp. 11570-11579. 